\title{
Saqer Sulaiman
}

\section{Risk Management in Palestinian Institutions}

The increase in the number of risks during the last decades triggers governments to search for the best ways to avert or mitigate these risks. The Palestinian Government is working in an unpredictable environment that rafts with risks and uncertainty due to the political instability and restrictions of occupation. Although there are many risks that the Palestinian institutions may face, this study focuses on two main interconnected ones. These two are the cut-off or decrease of the subsidies from international donors and the non-transfer of clearance revenues to the Palestinian National Authority by the Israeli Government. The likelihood of occurrence of these two risks and their impacts on the performance of the Palestinian institutions is pretty high. This study recommends a set of measures to decrease the effect of these two risks.

Keywords: risk management, international aids, clearance revenues, Palestinian National Authority, Palestinian Government

\section{Introduction}

The human concern for risk management is not a new one. Indeed, people have used multiple means to mitigate and confront risks. Recently, organised and structured studies have begun to analyse risks after the US spacecraft accident (Apollo) in January 1967, where three astronauts died in the fire. Prior to this incident, NASA had relied on the experience of practicing engineers to ensure quality and control. "In April 1969 new agency was formed to create new standards safety for spaceflight with a safety coefficient not less than $95 \%$, while the risk of death or injury to astronauts does not exceed 1\%" [1].

In recent years, risk management became one of the top priorities for all organisations, as it helps them to work in a more predictable and safer environment. The presence of a risk management policy or plan increases people's trust in the performance of organisations. Moreover, risk management makes stakeholders more confident that the organisation will achieve its desired outcomes, while minimising threats and their effects to acceptable levels, and maximising the chance of exploiting opportunities [2]. Therefore, this study aims to achieve the following purposes: 1. to increase the level of awareness of information on risk management; 2 . to identify the opportunities of risk management in the following two cases:

$*$ the non-transfer of clearance revenues to the Palestinian National Authority (PNA) by the Israeli Government

the cut-offs of the subsidies from international contributors to the PNA and recommend some policies and preventive measure to mitigate the impacts of this cut-off 


\section{Theoretical Framework}

Risk is any unexpected or unpredictable event that can be described as a combination of likelihood and consequences of that event. "At any project or task, there is the potential for opportunities or threats to success" [3]. Moreover, risk may be analysed in macro-, and micro-economic dimensions and risk management is often regarded as constituting a separate scientific area, which is applicable and utilitarian in character [4]. However, there are two types of risks. 1. Quantitative risks are those that can clearly be analysed by mathematical processes. They have an impact on time, people, money, or other resources. An example could be lost revenue, lost production, or delayed time. 2. Qualitative risks, on the other hand, are those that cannot (easily or clearly) be quantified. This may be because one does not have sufficient historical data to determine the likelihood of the risk and/or its impact is not understood well enough for a qualitative impact to be associated with it.

There are four ways through which the organisations can deal with risks: avoidance, transfer, mitigation and assumption. Table 1 shows the four possible ways to deal with risk.

Table 1.

The four possible ways to deal with risks. [Compiled by the Author's table.]

\begin{tabular}{|l|l|}
\hline Method & Activity \\
\hline Avoiding & Choose to change your plan to avoid the risky activity. \\
\hline Transferring & Find another business to finish and complete the activity. \\
\hline Mitigating & Take responsibility to eliminate the source of risk. \\
\hline Assuming & Complete the activity with full responsibility. \\
\hline
\end{tabular}

However, there is no best way nor panacea on how to deal with risks. The response depends mainly on the type and nature of the risk and the surrounding circumstances.

Risk management includes policies, activities and tools used to manage risks and avoid or reduce its effects. Thus, "risk management is the area where one can prevent risk and reduce the size of losses when it occurs and avoid its repetition in the future by studying the causes and the probability of the occurrence of each risk" [1]. Best Management Practices argues, since all kinds of organisations in all sectors public or private are exposed to a wide variety of risks, they have started moving towards focusing on and implementing formal risk management [5]. Indeed, government and organisations all over the world started to create legislation and regulations to enforce applying good governance principles and internal control inside the organisations.

Risk management is considered one of the major issues during strategic management processes in any organisation. The risk management process involves three basic phases, namely: 1. risk identification; 2. risk measurement; and 3. risk management [6]. Additionally, there are five steps of risk management processes: 1 . identification; 2 . understanding; 3. measurement; 4. management; and finally 5. assessment of the results [7].

The effective management of risks enables organisations to maximise opportunities and achieve their objectives and outputs [8]. The organisational functions of risk management may vary in range. It may consist of a single risk champion, or even a part-time risk manager, or even a full-scale risk management directorate. Its role includes the following [3]:

* Having policy and strategy for risk management. 
* Building a culture within the company by appropriate education about risk management.

* Having and developing internal risk strategy and structures for all business levels.

* Establishing and assessing processes for risk management.

* Coordinating the multi-purpose functional activities which supply data and information on risk management issues in the company.

* Updating risk response processes, with a contingency plan.

* Preparing reports on risks for the companies' executive.

\section{Risks That May Affect Palestinian Institutions}

The Palestinian institutions have to operate in an environment that is rich in a variety of risks. These include:

* interruptions of the production line or business processes arising from occupation restrictions, economic conditions and political instability;

$*$ cut-offs or decreases of the subsidies from international supporters;

$*$ unforeseen changes in existing strategic partnerships, key business relationships and vendor/supply sources;

* non-transfer of clearance revenues to the Palestinian National Authority by the Israeli Government;

* change in the labour market conditions affecting labour force availability and costs;

* lack of qualified specialists to implement government development plans and policies;

$*$ the emigration of highly skilled migrants to other countries;

$*$ loss of computerised data due to unexpected failure.

Here we will address only two of these risks: the cut-offs or decreases of the subsidies and the non-transfer of clearance revenues. Historically speaking, the probabilities of the occurrence of these two risks are to some extent high, moreover, the consequences of these risks are influential as the clearance revenues constitute the major component of the Palestinian budget. Also part of the expenditures depends mainly on international funds. The international and foreign aids to the Palestinians have contributed to financing the current and the development budgets, and especially it supports the Palestinian economy to cover a part of the deficit in the budget. The PNA's financial position has always been dependent on foreign aid, and so, exposed to the fluctuations of the political situation given the economic and political ties with Israel. Such vulnerability has impacted the size and nature of the domestic economic activity, as well as the revenues and expenditure of the PNA [9]. (Table 2.) On the other hand, the Israeli authorities sometimes violated the Paris Economic Protocol that had been signed between the PNA and the Israeli Government in order to organise the fiscal and monetary issues between the two parties. Moreover, the Israeli Government used this protocol to achieve political purposes, for example: "Israeli authorities bluntly hold over clearance revenues (which consist about $65 \%$ of Palestinian revenues) many times for political reasons" [10]. 
Table 2

Economic growth rate development of the rate of European aids and loans to the Palestinian National Authority (1994--2013). [11]

\begin{tabular}{|c|c|c|}
\hline Year & GDP growth rate & Rate of European aids and loans \\
\hline 1994 & 100.7 & 57.70 \\
\hline 1995 & 219.3 & 24.51 \\
\hline 1996 & 40.1 & 88.01 \\
\hline 1997 & 498.9 & 34.01 \\
\hline 1998 & 549 & 60.53 \\
\hline 1999 & 362.6 & -82.28 \\
\hline 2000 & -405.7 & 105.02 \\
\hline 2001 & -403.7 & 47.52 \\
\hline 2002 & -491.1 & 44.28 \\
\hline 2003 & 482.3 & 5.92 \\
\hline 2004 & 405.8 & 3.11 \\
\hline 2005 & 467.5 & 51.03 \\
\hline 2006 & -187.1 & -8.52 \\
\hline 2007 & 303.8 & 109.73 \\
\hline 2008 & 298.7 & 22.58 \\
\hline 2009 & 451.5 & -18.82 \\
\hline 2010 & 458.7 & -16.79 \\
\hline 2011 & 760 & -11.16 \\
\hline 2012 & 432.5 & -20.67 \\
\hline 2013 & 162.2 & 13.68 \\
\hline
\end{tabular}

The table above shows that international loans and aids fluctuated from year to year. It was the highest in 2007 and the lowest in 1999. This fluctuation related to political reasons and changes in the international donors' interests. Actually, some of their directive goals sometimes cause conflicts with the goals and priorities of the Palestinian policies. The main downside of international aids is that they have transformed the PNA from being a government to a kind of non-governmental organisation whose main job is to facilitate and organise the implementation of projects financed by donors.

\section{Discussion and Analysis of these two Risks}

The likelihood of occurrence of these two risks is pretty high as they are linked to political conditions and they practiced before, as though the Palestinian Government should prepare a risk management plan to respond to these risks in case they happen to become real. In the following pages, there are some suggestions for potential responses to these risks. 
Table 3.

The analysis of these two risks [Compiled by the author.]

\begin{tabular}{|l|l|l|l|l|l|}
\hline Risk & Risk category & $\begin{array}{l}\text { Risk likelihood } \\
\text { of occurrence }\end{array}$ & $\begin{array}{l}\text { Risk } \\
\text { consequences }\end{array}$ & $\begin{array}{l}\text { Inherent risk } \\
\text { rating }\end{array}$ & $\begin{array}{l}\text { Potential } \\
\text { mitigating } \\
\text { practice }\end{array}$ \\
\hline $\begin{array}{l}\text { Cut-offs or } \\
\text { decreases of the } \\
\text { subsidies from } \\
\text { international } \\
\text { donors. }\end{array}$ & $\begin{array}{l}\text { Financial and } \\
\text { governance. }\end{array}$ & $\begin{array}{l}\text { Likely - it has } \\
\text { occured more } \\
\text { than once in the } \\
\text { past. }\end{array}$ & $\begin{array}{l}\text { Modest, as the } \\
\text { percentage of } \\
\text { the international } \\
\text { aids fluctuated } \\
\text { over years and } \\
\text { has declined } \\
\text { in recent years } \\
\text { compared to the } \\
\text { 1990s. }\end{array}$ & Moderate risk. & $\begin{array}{l}\text { It must rely } \\
\text { upon mitigation } \\
\text { to some extent } \\
\text { and looking for } \\
\text { other possible } \\
\text { resources for } \\
\text { substitution. }\end{array}$ \\
\hline $\begin{array}{l}\text { Non-transfer } \\
\text { of clearance } \\
\text { revenues to } \\
\text { the Palestinian } \\
\begin{array}{l}\text { National } \\
\text { Authority by } \\
\text { the Israeli } \\
\text { Government. }\end{array}\end{array}$ & $\begin{array}{l}\text { Financial and } \\
\text { strategic. }\end{array}$ & $\begin{array}{l}\text { Likely-it has } \\
\text { occurred more } \\
\text { than once in } \\
\text { current times. }\end{array}$ & $\begin{array}{l}\text { Severe, as } \\
\text { delivery of } \\
\text { major services } \\
\text { cannot be } \\
\text { provided. }\end{array}$ & High risk. & $\begin{array}{l}\text { It must rely } \\
\text { upon to } \\
\text { mitigate risk to } \\
\text { some extent } \\
\text {-amendment } \\
\text { of the Paris }\end{array}$ \\
\hline
\end{tabular}

The Oslo Accords did not give the PNA full sovereignty on all the Palestinian territories. When talking about the Palestinian situation one should take into consideration that there is a significant difference between Palestine and other countries "as most of the Palestinian territories and people are still under occupation, and the government prevented from utilizing and using its natural resources" [10]. Whereas this is not the case in the independent countries, in which the governments have full sovereignty and power to access and utilise their national resources without external restrictions. In spite of the decrease in these aids during the last years, the debates about its role and impacts remain in the Palestinian scene as it increases the dependency of the Palestinian economy on external sources and deals with the PNA like a non-governmental organisation that depends on international aids to carry out its functions. It is important to mention, that the risk treatment strategy must be directed to sources as a preventive action as well as to impacts as a reactive action.

\section{How to Mitigate and Encounter these Risks}

The above-mentioned risks affect the performance of the government and undermine its ability to provide services to citizens. Thus, to maintain stability in organisational processes and continuity of governmental services, the Palestinian authorities should adopt a set of procedures, which can be summarised as follows:

\section{Short-term response}

The Palestinian institutions may find it advisable to adopt a combination of the following measures, which target the impacts of the afore-mentioned risks. 
* Reduction of non-core government expenditures, such as travel allowances for highrank officials and employees.

* Termination of contract employment and needless expert missions in order to reduce government expenditures and to transfer it into other vital sectors such as healthcare and education.

* Adoption of a risk management plan side by side with a strategic and developmental plan.

* Creation of a risk management department to be responsible for risk management and to act as the main body to organise the efforts and functions of risk management.

* Improvement of employee preparedness to deal with risks through targeted programs.

* Evolution of the legal framework to include incentives that encourage internal and external entrepreneurs to increase their investments in Palestine.

* Continuation of the efforts to secure the flow of Arab financial support to provide basic services for the population.

\section{Medium- and long-term response}

Furthermore, Palestinian institutions should adopt a combination of certain measures targeting the risk sources. First and foremost, 1. the abolition of the Paris Economic Protocol should be given high priority by the Palestinian economic decision-makers, as it is a major obstacle to build an independent and solid economy. Also, 2. the increase in the level of awareness of risk management in the Palestinian institutions should be furthered, since these institutions are still suffering from poor risk management culture. 3 . The reduction of wages may also be necessary by adopting the lowest rate of employment everywhere, with the exception of the Ministries of Health and Education. 4. The creation of new partnerships with other Arab countries can be considered, too, to import manufactured goods from Arab countries to meet the needs of the internal market. 5. The development of the management of the organisational incomes and internal funding by evolving a new system of tax collection and follow-up in order to prevent tax evasion. 6. Increase government revenues, in general, the public revenue progressed in recent years. 7 . It may be essential to develop the Palestinian tax collection system in order to achieve fairness in the tax burden, which is now larger for the poorer categories than for those who are less poor. 8. Enhance the level of partnership between the Government, non-governmental organisations and civil society. In general, non-governmental organisations play a vital role in providing some services to the poor and marginalised people, organising and implementing community-based activities. This in the long and medium-term run will involve the NGOs in social services to carry out a part of the responsibility side by side with the government. 9. Restructuring the public sector may ensure an efficient allocation of functions within the government and its ministries and institutions with clear responsibilities and accountability. It should be reflected in administrative structures to include a reduction in the size of the public sector and consolidation of all conflicted and overlapped departments in a way to ensure optimal use of available resources and enhance the efficiency and effectiveness of the government. 10. Achieving a balance between the various governmental sectors, including the re-consideration of agriculture as an important productive sector, and also the distribution of employees between administrative, vocational and professional jobs. Adoption of education and training policies for the youth and encourage them to work in higher professional jobs. This can improve the performance of the Palestinian 
economy and decrease the dependency on international subsidies. 11. Restoring confidence in the Palestinian institutions can be done by anchoring the principle of sustainability and professionalism of these Institutions, which is considered a vital issue, regardless of whether the government remains or changes. Good governance is essential and vital to show the world that the Palestinian Government has the ability to build its institutions and govern the country.

\section{Conclusion}

The Palestinian Government works in an unpredictable and unstable environment which increases the probabilities of risks. Moreover, the poor risk culture, organisational unpreparedness, shortage of experts and highly trained employees in the field of risk management and the application of immature risk management practices in Palestinian organisations increase the threats. They may be economic and administrative risks that can result in financial losses or non-financial ones that can bring about personal losses such as those of health and personal well-being.

The two main risks that have been addressed in this study were 1. cut-offs or decreases of the subsidies originating from international donors and 2. non-transfer of clearance revenues to the PNA by the Israeli Government. Actually, previous experience has shown that the abilities of the Palestinian Government to carry out their responsibilities and to provide services have been significantly affected by these two risks.

Considering the peculiarity of the situation of Palestine and the above-mentioned shortcomings, this study presents a set of recommendations to increase the preparedness of the Palestinian institutions to deal with the internal or external risks. These include, but are not limited to, the abolition of the Paris Economic Protocol, the restructuring of public sectors, the increase of the level of awareness of risk management in the Palestinian institutions, the adoption of risk management strategy and policies, the achievement of a balance between the various governmental sectors, including the re-consideration of agriculture as an important productive sector, the anchoring of the principles of sustainability and governance in the Palestinian Institutions, and, finally, the search for new partnerships either internally and externally to reduce the dependency on Israel as a sole source business partner.

\section{References}

[1] A. Abd Almonem, M., M. Al Kashef, and S. Kasib, Risk Management and Assessment, Centre for Higher Studies and Research, 2008.

[2] Her Majesty's Treasury, "The Orange Book: Management of Risk - Principles and Concepts", UK: Her Majesty's Treasury, 2004.

[3] British Standards Institution, "PD ISO/IEC Guide 73: 2002", Licence number 2002 SK/0313, London, BSI, 2002.

[4] K. Raczkowski, P. Tworek, "What Does Risk Management in an Economy Really Mean?" in Risk Management in Public Administration, Raczkowski, K. Ed. Cham, Switzerland: Springer International Publishing AG, 2017. DOI: https://doi.org/10.1007/978-3-319-30877-7_1

[5] Best Management Practice, Management of Risk Guidance for Practitioners, $3^{\text {rd }}$ edition, London: Axelos, 2010. 
[6] E. Banks, The Credit Risk of Financial Instruments, London: Macmillan Business, 1993, pp. 19-23. DOI: https://doi.org/10.1007/978-1-349-13247-8_2

[7] D. Iverson, Strategic Risk Management: A Practical Guide to Portfolio Risk Management, Singapore: John Wiley and Sons, 2013. DOI: https://doi.org/10.1002/9781118638828

[8] Australian Capital Territory Insurance Authority, "Guide to Risk Management," Australian Capital Territory Insurance Authority, 2004, [Online]. Available: https: //apps.treasury.act. gov.au/insurance-and-risk-management/risk-management

[9] A. Qubaja, "Fiscal Sustainability of the Palestinian National Authority, Experience and Future Prospects," Palestine Economic Policy Research Institute, 2012.

[10] O. Al-Razeq, "Assessing Fiscal Policies of the Palestinian National Authority," Ramallah: Palestine Economic Policy Research Institute (MAS), 2016.

[11] N., H. Abou Jameh, A., F. Abou Jameh, "The Impact of European Loans and Aid on the Palestinian Economy," 2017.

\section{A PALESZTIN KOCKÁZATKEZELÉS INTÉZMÉNYRENDSZERE}

A növekvő számú kockázati tényezők miatt a kormányok igyekeznek a legjobb módszereket megtalálni ezek enyhitésére vagy megelözésére. A palesztin kormány kiszámíthatatlan környezetben dolgozik, amelyet a politikai instabilitás és a megszállás korlátozásai miatti kockázat és bizonytalanság okoz. Annak ellenére, hogy a palesztin intézményeknek sok kockázattal kell szembenézniük, ez a tanulmány két fö, egymással összefüggö kockázatra összpontosít. Ez a két kockázat a nemzetközi adományozóktól származó támogatások megvonása vagy csökkentése, valamint az izraeli kormány által a palesztin nemzeti hatóságnak nyújtott adóbevételek kifizetésének elmulasztása. A két kockázat előfordulásának valószínüsége és azok hatása a palesztin intézmények teljesítményére meglehetősen magas. Ez a tanulmány olyan intézkedéseket javasol, amelyek csökkenthetik e két kockázat hatását.

Kulcsszavak: kockázatkezelés, nemzetközi segélyek, adóbevételek, Palesztin Nemzeti Hatóság, Palesztin Kormány

Sager Sulaiman

PhD-hallgató

Nemzeti Közszolgálati Egyetem

Közigazgatás Tudományi Doktori Iskola

Saqersul@yahoo.com

https://orcid.org/0000-0002-4866-7694
Saqer Sulaiman

PhD Student

National University of Public Service

Doctoral School of Public Administration Science

Sagersul@yahoo.com

https://orcid.org/0000-0002-4866-7694

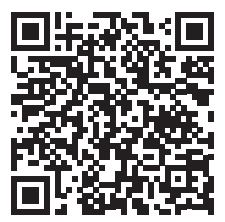

http://journals.uni-nke.hu/index.php/reptudkoz/article/view/433/175 